\section{Fludd's philosophy}

\section{P. M. Rattansi}

Robert Fludd and His Philosophicall Key. Introduction by Allen G. Debus. Pp.156. (Neale Watson: New York, 1979.) $\$ 40, £ 20$.

IN 1620 Francis Bacon published his Novum Organum, with a dedication to James I, urging him to support his enterprise, "that so at length, after the lapse of so many ages, philosophy and the sciences may no longer float in air, but rest on the solid foundation of experience of every kind ...". At about the same time, the physician Robert Fludd had completed a Philosophicall Key "to unlock and open the meanings of that Macrocosmicall and Microcosmicall Philosophy'. He, too, dedicated it to James I, hoping the King's patronage would shield him "from the Harpys talents and envious endeavours of this World"'.

Fludd agreed with Bacon that Aristotelian science was to be replaced by one based on "ocular demonstration" and dedicated to the relief of human misery. Like him, he praised atomism, but was more inclined to explain nature's operations in terms of a 'spirit' active in all things. But Fludd believed in a 'Christian' philosophy of nature, the principles of which would be drawn from the account of creation in the text of Genesis. Bacon condemned the "unwholesome mixture of things human and divine" since it gave rise to "not only a fantastic philosophy but also an heretical religion". Fludd associated the greatest secret in nature, the principle of life, with light and the breath of the Lord, while Bacon denounced such notions as "superstitious".

His major works had already appeared in Latin, and had involved Fludd in controversies with Kepler, Mersenne and Gassendi. The Key was written in English to silence critics at home. Fludd thought his "experimental demonstrations" would convince readers of the truth of his ideas. Relying on an analogy between the Sun in the Universe, the heart in the human body, gold in the metalline and wheat in the vegetable kingdoms, Fludd chose to concentrate on experiments on wheat. After all, had it not been compared to the Second Person of the Trinity, and was it not Christ's referring to bread as his body which had set the Christian world "in combustion"?

The planting of the seed in the ground and the generation of wheat had exemplified the pattern of death and resurrection to the Christian alchemist. Fludd pointed out that as the plant grew, the quintessence in it rose to the stalk and was concentrated in the wheat grain. By a sympathetic magnetism, the most spiritual part of the plant would then draw down more and more of the aerial spirit. This process could be emulated by the chemist, and Fludd believed he had succeeded in obtaining the universal spirit in the form of a "white christalline" substance.

Fludd's claims may seem extravagent to us, his reasoning contorted and his "ocular demonstrations" quite unconvincing. It is discomforting, therefore, to recognize in his work themes which recent historical research has unearthed in the alchemical studies which occupied a great deal of Isaac Newton's most creative period: the true interpretation of the alchemical foundation text, the 'Emerald Tablet'; the 'magnet' to draw down the aerial quintessence; and the involvement of light in generation in the three kingdoms of

\section{Recombination in phage and fungi}

\section{H.L.K. Whitehouse}

Genetic Recombination: Thinking about it in Phage and Fungi. By F. W. Stahl. Pp.333. (Freeman: San Francisco and Oxford, 1979.) $£ 12.90$.

THE publication of a book on genetic recombination by one of the leading workers in the field is an important event for geneticists. Recombination was discovered in the early years of this century and became a central issue in genetics with the realization that exchange of segments between homologous chromosomes was involved, in addition to the random orientation of the paternal and maternal members of each chromosome pair on the spindle at the first meiotic division. Recombination took on a new dimension about 30 years ago with the discovery of its occurrence in prokaryotes, and with the recognition that both in prokaryotes and eukaryotes understanding the process of exchange was likely to require detailed knowledge of the biochemistry of DNA. Since that time it has been essential, if a general view of the subject was to be obtained, that results derived from prokaryotes and eukaryotes should be integrated. To achieve such integration is difficult, as the life-cycles, and therefore the experimental techniques and kind of information obtained, are so different: the prokaryote- and the eukaryote-worker speak such different languages that they may barely understand one another. It is greatly to Stahl's credit that he has attempted in this book to bring about a synthesis of results from bacteriophages and from fungi, as these are the organisms that have contributed most from each kingdom. The phages discussed are lambda and T4 of Escherichia coli. nature. He represents a style of thought which cannot be neglected if we are fully to comprehend those whom we recognize as the pioneers of modern science.

The Key has been published for the first time from the manuscript at Trinity College, Cambridge, with an Introduction by Allen G. Debus. The text itself occupies 93 pages and has been supplemented with an extensive account of the life and work of Fludd. The work, written in a rhapsodic style which occasionally breaks into verse, makes Fludd's ideas a little more accessible to the modern reader.

P. M. Rattansi is Professor in the Department of History and Philosophy of Science, University College, University of London, UK.

The first two chapters give the basic information about the exchange process obtained from progeny chosen on a random basis, in fungi and phages, respectively; and the next two chapters give the fuller picture when both products of an exchange are recovered - that is, tetrad analysis and single burst analysis. The implications of the duplex structure of DNA are introduced in Chapter 5. Then follows an important chapter on the surprising results that have been obtained, both in phages and fungi, from investigations with very closely linked mutants. Together with an appendix giving the algebraic basis of the concepts introduced, this chapter constitutes one quarter of the entire book. The following two are concerned with conversion and its association with crossing-over; and, after a consideration of recombination chemistry, the book concludes with lengthy discussions of current hypotheses. There is no account of transposons or phage Mu.

The lay-out of the chapters, although logical, does not necessarily make the subject matter easy to comprehend, and certainly leads to considerable repetition. Thus, having learnt in the first chapter that crossing-over takes place between homologous chromosomes, one has in a later chapter to replace this with the notion that the exchanges occur between daughter chromatids rather than whole chromosomes. Again, in discussing aberrant asci, one of the five basic kinds is treated in a different chapter from the others, because it does not have unequal numbers of the two parental genotypes and therefore does not qualify for consideration in a chapter on conversion. Yet all the types of aberrant segregation are associated with crossing. over and it is arguable that the simplest approach is to treat them all together.

Some of the difficulty for students in understanding what is known about genetic recombination derives from complexities inseparable from the organisms investigated. Thus, in lambda not only are there two recombination 